\title{
MILK PRODUCTION AND THE FEEDING COSTS OF LACTATING SAANEN GOATS FED DIETS CONTAINING SPINELESS CACTUS ${ }^{1}$
}

\author{
LUCIANA FELIZARDO PEREIRA SOARES ${ }^{2}$, AGNI MARTINS NUNES CORRÊA ${ }^{2}$, ANDREIA FERNANDES DE \\ SOUZA $^{2}$, FRANCISCO FERNANDO RAMOS DE CARVALHO ${ }^{2}$, MICHEL DO VALE MACIEL ${ }^{3}$
}

\begin{abstract}
A new spineless cactus genotype (Orelha de Elefante Mexicana) is being used in the diets of dairy animals raised in semiarid regions. However, little is known about its impact on goat milk production and feeding costs. The objective of this study was to evaluate the milk production and costs of feeding lactating Saanen goats with diets containing the spineless cactus Orelha de Elefante Mexicana (OEM) as a replacement for the Miúda (MIU) spineless cactus. Ten Saanen goats with an average initial weight of $50 \pm 5.6 \mathrm{~kg}$ were assigned to two $5 \times 5$ Latin-square designs. The diets consisted of replacing MIU with four levels of OEM $(0 \%$, $11.5 \%, 23.5 \%$, and $35 \%$, on a dry matter basis) and a control based on Tifton hay. The diet with $35 \%$ OEM had lower costs per kg dry matter $(\$ 0.32)$ as well as lower daily feed costs $(\$ 0.29 / \mathrm{d})$. The dry matter intakes and milk yields $(3.21 \mathrm{~kg} / \mathrm{d})$ did not differ $(\mathrm{P}>0.05)$ between the OEM replacement levels. The use of up to $35 \%$ MIU or OEM spineless cactus in the Saanen goat diet maintains milk production levels and decreases feed production costs.
\end{abstract}

Keywords: Intake. Dactylopius opuntiae. Opuntia stricta (Haw.) Haw. Economic performance.

\section{PRODUÇÃO DE LEITE E CUSTOS DA ALIMENTAÇÃO DE CABRAS SAANEN EM LACTAÇÃO RECEBENDO DIETAS CONTENDO PALMA FORRAGEIRA}

RESUMO - Um novo genótipo de palma forrageira está sendo utilizado nas dietas de animais leiteiro, criadas em regiões semiáridas. Contudo, pouco se sabe sobre seu impacto na produção de leite de cabras e nos custos com alimentação. Objetivou-se com este estudo avaliar a produção de leite e os custos da alimentação de cabras da raça Saanen em lactação recebendo dietas contendo palma orelha de elefante mexicana (OEM) em substituição a palma miúda (MIU). Foram utilizadas dez cabras com peso inicial de $50 \pm 5,6 \mathrm{~kg}$ distribuídas em duplo quadrado latino 5 x 5 . As dietas consistiram em substituir MIU por quatro níveis de OEM $(0 \%$; $11,5 \%$; $23,5 \%$ e $35 \%$, com base na matéria seca) e uma dieta controle com feno de tifton. A dieta com $35 \%$ de OEM teve custos mais baixos por $\mathrm{kg}$ de matéria seca $(\$ 0,32)$, bem como menores custos diários de alimentação $(\$ 0,29 / \mathrm{d})$. A ingestão de matéria seca e a produção de leite $(3,21 \mathrm{~kg} / \mathrm{d})$ não diferiram $(\mathrm{P}>0,05)$ entre os níveis de substituição de OEM. O uso de até $35 \%$ de MIU ou OEM na dieta de cabras Saanen mantém os níveis de produção de leite e diminui os custos de alimentação.

Palavras-chave: Consumo. Dactylopius opuntiae. Opuntia stricta (Haw.) Haw. Rentabilidade econômica.

\footnotetext{
${ }^{*}$ Corresponding author

${ }^{1}$ Received for publication in $09 / 16 / 2019$; accepted in $03 / 25 / 2020$.

Paper extracted from the monograph of the second author.

${ }^{2}$ Animal Science Department, Universidade Federal Rural de Pernambuco, Recife, PE, Brazil; 1fpmsoares@gmail.com - ORCID: 00000003-3504-3783, agnimartinsnunes@gmail.com - ORCID: 0000-0002-0021-1612, andreia.souza@ufrpe.br - ORCID: 0000-0003-4992678X, ffrcarvalho@gmail.com - ORCID: 0000-0001-9211-0263.

${ }^{3}$ Animal Science Department, Universidade Federal do Amazonas, Parintins, AM, Brazil; micheldr_el@hotmail.com - ORCID: 0000-0002 $-6483-224 X$.
} 


\section{INTRODUCTION}

The semiarid regions of the world are characterized by limited food resources and reduced fodder availability during the dry periods of the year, when animals must be supplemented with concentrated and bulky feed. A search for natural resources to meet the nutritional requirements for maintaining milk production during this critical period is needed.

The spineless cactus was a strategic solution, because it had adaptive characteristics that allowed for its development, and it is now considered an important feed source (MAHOUACHI; ATTI; HAJJI, 2012). Its high water-use efficiency and biomass yield justify its importance to these regions (BEN SALEM, 2010; GUSHA et al., 2015). When associated with a fiber source, this cactus can be used in the ruminant diet as an energy source provided the nutritional deficiencies are corrected (INÁCIO et al., 2020). When Lopes et al. (2017) evaluated diets with $400 \mathrm{~g} / \mathrm{kg}$ dry mass (DM) of the Miúda spineless cactus in dairy goats, they found no difference in milk production.

Many varieties of spineless cactus can be grown in the arid and semiarid regions of the world, including some with low pest risks such as the spineless cacti Orelha de Elefante Mexicana [OEM; Opuntia stricta (Haw.) Haw.] and Miúda (MIU; Nopalea cochenillifera Salm Dyck). As OEM has a lower water demand (DONATO et al., 2014) and produces more dry-matter per hectare $(37 \mathrm{t} \mathrm{DM} / \mathrm{ha} / 2$ years) than MIU (21 t DM/ha/ 2 years) (SANTOS et al., 2013), it is a feasible option for reducing the costs associated with animal feed, which represent the largest portion of production operational costs (OGOLA; NGUYO; KOSGEY, 2010).

There are studies on the use of OEM palm in the dairy cow diet (INÁCIO et al., 2020; SILVA et al., 2018), but the use of this cactus, which is resistant to carmine cochineal (Dactylopius opuntiae), has been little studied in dairy goats. Providing a semiarid and pest resistant fodder is a strategic way to reduce the costs of acquiring the quality bulky ingredients needed to ensure yearround milk production, reducing instability for milkproducing farms. Our goal with this study was to evaluate the feed costs and milk production of lactating Saanen goats fed diets containing OEM as a replacement for MIU spineless cactus.

\section{MATERIAL AND METHODS}

The experimental test was developed in the dairy goat sector of the animal sciences division of the Rural Federal University of Pernambuco, Brazil $\left(08^{\circ} 04^{\prime} 03^{\prime \prime} \mathrm{S}, \quad 34^{\circ} 55^{\prime} 00^{\prime \prime} \mathrm{W}\right)$. According to the Köppen climate classification, the predominant climate is As'.

This research was conducted according to the institutional committee on animal use (License $\left.\mathrm{N}^{\mathrm{o}} 059 / 2016\right)$. The experiment involved 10 Saanen goats weighing $50 \pm 5.6 \mathrm{~kg}$ allocated into two $5 \times 5$ simultaneous Latin squares. The experiment lasted 95 days in total, which were divided into five 19-day experimental periods. The 19-day experiments were periodized with Days 1-14 as the diet-adaptation periods and Days 15-19 as the data and sample collection (intake, leftover, and milk yield) periods. The animals were housed in individual stalls with individual feeders and drinkers.

The diets consisted of four levels $[0 \%, 11.5 \%$, $23.5 \%$, and $35 \%$ on a dry matter (DM) basis] of OEM spineless cactus as a replacement for MIU and a control diet commonly adopted in the region for dairy goats based on Tifton hay, corn, and soybean meal. The experimental diets (Table 1) were formulated as recommended by the NRC (2007), with the composition of the ingredients based on the requirements of dairy goats with a $3.5 \mathrm{~kg} / \mathrm{d}$ average yield of $3.5 \%$ milk fat.

Table 1. Proportion of ingredients and chemical composition of the experimental diets.

\begin{tabular}{|c|c|c|c|c|c|}
\hline \multirow{2}{*}{ Ingredients $(\mathrm{g} / \mathrm{kg})$} & \multirow[b]{2}{*}{ Control } & \multicolumn{3}{|c|}{ OEM levels (\%) } & \multirow[b]{2}{*}{35} \\
\hline & & 0 & 11.5 & 23.5 & \\
\hline Tifton hay & 500 & 150 & 150 & 150 & 150 \\
\hline Miúda & 0 & 350 & 235 & 115 & 0 \\
\hline Orelha de Elefante Mexicana (OEM) & 0 & 0 & 115 & 235 & 350 \\
\hline Ground corn & 308 & 318 & 317 & 316 & 315 \\
\hline Soybean meal & 160 & 160 & 160 & 160 & 160 \\
\hline Urea/AS ${ }^{1}$ & 2.0 & 7.0 & 7.5 & 8.5 & 9.5 \\
\hline Calcitic limestone & 15.0 & 0 & 0 & 0 & 0 \\
\hline Salt & 5.0 & 5.0 & 5.0 & 5.0 & 5.0 \\
\hline Mineral & 10 & 10 & 10 & 10 & 10 \\
\hline \multicolumn{6}{|l|}{ Chemical Composition (g/kg dry matter) } \\
\hline Dry matter & 883 & 255 & 268 & 283 & 300 \\
\hline Organic matter & 923 & 925 & 927 & 929 & 931 \\
\hline Crude protein & 171 & 166 & 166 & 167 & 168 \\
\hline Neutral detergent fiber ${ }^{2}$ & 404 & 236 & 240 & 244 & 247 \\
\hline Non-fiber carbohydrates & 326 & 498 & 496 & 493 & 490 \\
\hline
\end{tabular}

${ }^{1} 9$ parts urea and 1 part ammonium sulfate (AS). ${ }^{2}$ Corrected for ash and protein. 
The diets were provided to the animals twice daily (08:00 and 15:30) immediately after milking with the amount of feed supplied corrected daily to generate $10 \%$ orts in the fresh matter. Samples of the feed and orts were collected daily during each experimental period.

The goats were milked twice a day (06:30 and 15:00), and the milk production was recorded from Days 15-19 for each experimental period. Milk samples were collected from both milking periods, and after the last collection, combined for each goat.

Milk samples were analyzed for fat content according to ISO 9622/IDF $141 \mathrm{C}$ (ISO, 2013). The milk-yield values were corrected for a $3.5 \%$ fat content (SKLAN et al. 1992) using the equation: FCM $\left(\mathrm{kg} \cdot \mathrm{day}^{-1}\right)=(0.4255 \times$ milk production $)+$ $[(16.425 \times(\%$ milk fat $/ 100) \times$ milk production $]$. The feed and ort samples were analyzed to determine the DM, mineral matter, and crude protein concentrations according to AOAC (2010).

The OEM and MIU spineless cacti were purchased directly from producers, and the other feed ingredients were purchased on the local market according to the prices in force during the second half of 2017. The cost and revenue indicators and the measures of economic success were calculated (PINHO et al., 2017) to determine the following: Total revenue $(\$$ per day $)=$ milk production multiplied by the price of a $\mathrm{kg}$ of milk; Additional revenue $(\$$ per day $)=$ difference between the total income obtained by each treatment and the total income obtained by the control treatment; Daily feed cost $(\$$ per goat $)=$ total cost of food for each treatment; Additional cost $(\$$ per day $)=$ difference between the total cost of food for each treatment and the total cost for the control treatment; Additional profit $(\$$ per day) $=$ difference between the amount of additional revenue and the amount of additional cost; Feeding cost per $\mathrm{kg}$ of milk produced $(\$)=$ ratio between the daily cost of feeding and the amount of milk production.

The data were submitted to an analysis of variance and regression $(\mathrm{P}<0.05)$. For the purposes of the treatments, the following orthogonal contrasts were performed: I - control treatment versus $35 \%$ MIU spineless cactus treatment; II - control treatment versus $35 \%$ OEM spineless cactus treatment; and III - 35\% MIU versus 35\% OEM treatments. Data from spineless cacti treatments were used for the regression analysis.

The data were analyzed using the PROC MIXED procedure in the statistical package SAS (Statistical Analysis System, version 9.2) according to the following model:

$$
\mathrm{Y}_{\mathrm{ijkl}}=\mu+\mathrm{T}_{\mathrm{i}}+\mathrm{Q}_{\mathrm{j}}+\mathrm{P}_{\mathrm{k}}+(\mathrm{A} / \mathrm{Q})_{\mathrm{lj}}+\mathrm{T}^{*} \mathrm{Q}_{\mathrm{ij}}+\varepsilon_{\mathrm{ijkl}},
$$

where $Y_{i j k l}=$ observation ijkl; $\mu=$ general mean; $T_{i}=$ treatment fixed effect $i ; Q_{j}=$ square fixed effect $j$; $\mathrm{P}_{\mathrm{k}}=$ period fixed effect $\mathrm{k} ;(\mathrm{A} / \mathrm{Q})_{\mathrm{lj}}=$ animal 1 into square $\mathrm{j}$ random effect; $\mathrm{T}^{*} \mathrm{Q}_{\mathrm{ij}}=$ interaction effect of treatment $\mathrm{i}$ and square $\mathrm{j}$; and $\varepsilon_{\mathrm{ijkl}}=$ random error with mean 0 and variance $\sigma 2$.

\section{RESULTS AND DISCUSSION}

Due to the similarity in the chemical compositions of the diets, the replacement of MIU with OEM had no affect $(\mathrm{P}>0.05)$ on DM consumption (Table 2), which is probably regulated by physiological factors (MERTENS, 1994). Because the diets with palm contained low neutral detergent fiber levels, the high levels of non-fiber carbohydrates added to the rapid ruminal degradability of the DM (BEN SALEM et al., 1996).

After considering the nutrient balancing requirements and the production potential of the animals, no differences $(\mathrm{P}>0.05)$ were observed in the milk yield or milk production corrected to a $3.5 \%$ fat content. This was due to the absence of an effect on the DM consumption for the evaluated treatments. In addition, replacing the MIU with OEM did not alter $(\mathrm{P}>0.05)$ the milk fat content (Table 2), which can be explained by the similarity in their chemical compositions and the lack of difference in dietary intake. It is worth noting that the OEM and MIU spineless cacti have the potential to be used in the diet of lactating goats without altering milk production and fat content. These results corroborate the importance of spineless cactus to the dairy system of small producers in semiarid regions (BEN SALEM, 2010; MAHOUACHI; ATTI; HAJJI, 2012).

Table 2. Dry matter intake, milk yield, and fat content for the goats fed different OEM diets.

\begin{tabular}{|c|c|c|c|c|c|c|c|c|c|c|c|c|}
\hline \multirow{2}{*}{ Item } & \multirow{2}{*}{ Control } & \multicolumn{4}{|c|}{ OEM levels (\%) } & \multirow[b]{2}{*}{ SEM } & \multirow[b]{2}{*}{ ANOVA } & \multicolumn{3}{|c|}{$\begin{array}{c}\text { P Value } \\
\text { Contrasts* }\end{array}$} & \multirow[b]{2}{*}{ Linear } & \multirow[b]{2}{*}{ Quadratic } \\
\hline & & 0 & 11.5 & 23.5 & 35 & & & I & II & III & & \\
\hline DM Intake $(\mathrm{kg} / \mathrm{d})$ & 2.06 & 2.56 & 2.44 & 2.59 & 2.60 & 0.58 & 0.77 & - & - & - & 0.740 & 0.602 \\
\hline Milk (kg/d) & 2.93 & 3.22 & 3.28 & 3.26 & 3.39 & 0.75 & 0.645 & - & - & - & 0.986 & 0.959 \\
\hline $3.5 \%$ FCM $(\mathrm{kg} / \mathrm{d})$ & 2.60 & 2.82 & 2.77 & 2.81 & 2.80 & 0.79 & 0.591 & - & - & - & 0.987 & 0.933 \\
\hline Fat $(\mathrm{g} / 100 \mathrm{~g})$ & 2.80 & 2.73 & 2.53 & 2.63 & 2.41 & 0.46 & 0.145 & - & - & - & 0.183 & 0.804 \\
\hline
\end{tabular}

*I - control diet versus 35\% Miúda (MIU) spineless cactus diet; II - control diet versus 35\% Orelha de Elefante Mexicana (OEM) spineless cactus diet; and III - 35\% MIU diet versus 35\% OEM diet. ANOVA, analysis of variance; DM, dry matter; FCM, fat-corrected milk yield; SEM, standard error of the mean. 
A lower cost per $\mathrm{kg}$ DM was obtained (Table 3) with the $35 \%$ OEM diet. This is explained by the higher DM content in the OEM composition (14.2\%) compared to that of MIU (11.3\%), resulting in the MIU cost per $\mathrm{kg}$ DM being higher than that for OEM. The price of the control feed was $\$ 0.44 / \mathrm{kg}$
DM, with the Tifton-85 hay $(\$ 0.57 / \mathrm{kg} \mathrm{DM})$ as the costliest feed ingredient. This increase in the price of bulky ingredients is due to the supply and demand relationship in the region (OGOLA; NGUYO; KOSGEY, 2010).

Table 3. Economic performance indicators.

\begin{tabular}{lccccc}
\hline & \multirow{2}{*}{ Control } & \multicolumn{4}{c}{ OEM levels (\%) } \\
\cline { 3 - 6 } & & 0 & 11.5 & 23.5 & 35 \\
\hline Cost of diet (\$ per kg dry matter) & 0.44 & 0.34 & 0.34 & 0.33 & 0.32 \\
Daily feed cost (\$ per goat) & 0.92 & 0.89 & 0.84 & 0.83 & 0.80 \\
Price of milk (\$ per kg) & 0.77 & 0.77 & 0.77 & 0.77 & 0.77 \\
Total revenue (\$ per day) & 2.00 & 2.17 & 2.13 & 2.16 & 2.16 \\
Additional revenue (\$ per day) & - & 0.17 & 0.13 & 0.16 & 0.15 \\
Additional costs (\$ per day) & - & -0.03 & -0.08 & -0.09 & -0.12 \\
Additional profit (\$ per day) & - & 0.20 & 0.21 & 0.25 & 0.27 \\
Feeding cost per kg milk produced (\$) & 0.35 & 0.33 & 0.30 & 0.30 & 0.29 \\
\hline
\end{tabular}

Brazilian Reais quotation for U.S. dollar in September 2017: R\$ 3.23. Costs (\$ per kg dry matter): Tifton hay (0.57), Miúda (0.27), OEM (0.22), ground corn (0.24), soybean meal (0.49), urea/AS (0.56), calcitic limestone (0.12), and salt (0.99). OEM, Orelha de Elefante Mexicana.

The $0 \%$ OEM diet had the best economic performance in terms of total revenue (Table 3 ). This was due to the higher average milk production. The additional income for this diet was also the highest, because this economic performance indicator was obtained by calculating the difference between the total incomes of the diet with an OEM replacement and the control diet.

Regarding daily food costs, because it had the lowest cost per $\mathrm{kg} \mathrm{DM}$, the 35\% OEM diet had the lowest costs (Table 3). Further, due to the difference with the control treatment, the $35 \%$ OEM diet also had the least amount of additional feed costs.

All the OEM replacement groups had negative values relative to additional cost because the daily food costs for all the experimental diets were less than that of the control diet. The additional profit for the $35 \%$ OEM diet was highest due to the difference between the additional income and the additional negative cost.

Diets with OEM reduced the production costs per $\mathrm{kg}$ of milk. The lowest value was observed for the $35 \%$ OEM diet at $\$ 0.94 / \mathrm{kg}$ milk, followed by the $23.5 \%$ OEM diet at $\$ 0.29 / \mathrm{kg}$ milk (Table 3), resulting in $17.5 \%$ and $16.7 \%$ higher cost-benefit ratios, respectively, relative to the control diet. This is because they had the lowest daily feed costs (\$0.80/d and $\$ 0.83 / \mathrm{d}$, respectively), with no variation in milk production $(\mathrm{P}>0.05)$.

Despite the lower cost per $\mathrm{kg}$ milk obtained with the 35\% OEM diet, all the diets with spineless cactus had lower costs relative to the control diet. However, the positive effects on milk production costs coupled with OEM's nutritional aspects and resistance to the carmine cochineal pest reinforce the importance of this cactus for the maintenance of dairy goats in semiarid regions (GOVEIA et al, 2016).

\section{CONCLUSION}

The use of up to $35 \%$ MIU or OEM spineless cactus in the diet of Saanen goats maintains milk production levels and decreases feed production costs.

\section{REFERENCES}

ASSOCIATION OF OFFICIAL ANALYTICAL CHEMISTS - AOAC. Official methods of analysis. 18th ed. Gaithersburg, Maryland, USA. 2010.

BEN SALEM, H. Nutritional management to improve sheep and goat performances in semiarid regions. Brazilian Journal of Animal Science, 39: 337-347, 2010.

BEN SALEM, H. et al. Effect of increasing level of spineless cactus (Opuntia ficus indica var. inermes) on intake and digestion by sheep given straw-based diets. Animal Science, 62: 293-299, 1996.

DONATO, P. E. R. et al. Morfometria e rendimento da palma forrageira 'Gigante' sob diferentes espaçamentos e doses de adubação orgânica. Revista Brasileira de Ciências Agrárias, 9: 151-158, 2014.

GOVEIA, J. S. S. et al. Partial replacement of corn by forage cactus in the diets of lactating goats. Semina: Ciências Agrárias, 37: 969-976, 2016. 
GUSHA, J. et al. The effect of Opuntia ficus indica and forage legumes based diets on goat productivity in smallholder sector in Zimbabwe. Small Ruminant Research, 125: 21-25, 2015.

INÁCIO, G. J. et al. Nutritional and performance viability of cactus Opuntia-based diets with different concentrate levels for Girolando lactating dairy cows. Asian-Australasian Journal of Animal Science, 33: 35-43, 2020.

ISO 9622/IDF 141C. Determination of milk fat, protein, lactose, and urea content: Guidance on the operation of mid-infrared instruments, Brussels, Belgium. 2013.

LOPES, L. A. et al. Replacement of tifton hay with alfalfa hay in diets containing spineless cactus (Nopalea cochenillifera Salm-Dyck) for dairy goats. Small Ruminant Research, 156: 7-11, 2017.

MAHOUACHI, M.; ATTI, N.; HAJJI, H. Use of spineless cactus (Opuntia ficus indica $f$. inermis) for dairy goats and growing kids: Impacts on milk production, kid's growth, and meat quality. The Scientific World Journal, 2012: ID 321567, 2012.

MERTENS, D. R. Regulation of forage intake. In: FAHEY, G. C. (Ed.) Forage quality, evaluation, and utilization. Madison, WI: American Society of Agronomy, 1994. cap. 11, p. 450-493.

NATIONAL RESEARCH COUNCIL - NRC. Nutrient requirements of small ruminants, 7 th ed. National Academic Press, Washington, DC, 2007. 292 p.

OGOLA, T. D.; NGUYO, W. K.; KOSGEY, I. S. Economic contribution and viability of dairy goats: implications for a breeding programme. Tropical Animal Health and Production, 42: 875-885, 2010.

PINHO, D. B. et al. Manual de economia. 7. ed. São Paulo, SP: SARAIVA, 2017. 734 p.

SANTOS, D. C. et al. Estratégias para uso de cactáceas em zonas semiáridas: novas cultivares e uso sustentável das espécies nativas. Revista Científica de Produção Animal, 15: 111-121, 2013.

SILVA, R. C. et al. Orelha de Elefante Mexicana (Opuntia stricta [Haw.] Haw.) spineless cactus as an option in crossbred dairy cattle diet. South African Journal of Animal Science, 48: 516-525, 2018.

SKLAN, D. et al. Fatty acids, calcium soaps of fatty acids and cottonseeds fed to high yielding cows. Journal of Dairy Science, 75: 2463-2472, 1992. 